\title{
Household Responses to Livelihood Transformation in Peri-Urban Kumasi
}

\author{
Kabila Abass ${ }^{1}$, Kwadwo Afriyie ${ }^{1} \&$ Janet Afua Abrafi Adomako ${ }^{1}$ \\ ${ }^{1}$ CASS, Faculty of Social Sciences, Department of Geography and Rural Development, Kwame Nkrumah \\ University of Science and Technology, Kumasi, Ghana \\ Correspondence: Kabila Abass, CASS, Faculty of Social Sciences, Department of Geography and Rural \\ Development, Kwame Nkrumah University of Science and Technology, Kumasi, Ghana. Tel: 233-244-580-883. \\ E-mail: abakabila@yahoo.com
}

Received: March 8, 2013 Accepted: April 23, 2013 Online Published: May 30, 2013

doi:10.5539/jsd.v6n6p121 URL: http://dx.doi.org/10.5539/jsd.v6n6p121

\begin{abstract}
This study examines household responses to livelihood transformation in the Kumasi peri-urban area. The main tools used in the data collection are household survey, key informants interviews and focus group discussions. Quantitative data are presented using tables, graphs and charts while direct quotations from respondents are used to present qualitative data. The study identifies both farm and non-farming livelihood strategies as the main livelihood strategies households adopt in the study communities. The study shows that most households rarely depend on one strategy to survive. However, non-farming households have more diversified livelihood strategies than farming households. The social network support base is also identified to play a very important role in the livelihood of respondents. Since farming still remains a very important component of livelihood strategies in the communities, some form of sanity needs to be injected in the land market. The study thus recommends a speed up work on the urban policy while the land policy needs to be fully implemented. The Land Administration Project must also be fast-tracked to bring harmony in the land market. Moreover, interventions to provide alternative means of livelihood to farmers who have lost their farm lands due to urbanisation can be made. Building the capacity of the peri-urban poor through skills training and access to credit and infrastructure facilities is a viable option. This will ensure a proper integration of peri-urban dwellers into urban monetary economy.
\end{abstract}

Keywords: urbanisation, peri-urban, livelihood, coping strategies, Kumasi

\section{Introduction and Background}

The effects of urban expansion can be two edged sword. This is documented as mosaic of opportunities and threats to people living in peripheral villages (Aberra \& King, 2005; Xie et al., 2007; Olujimi, 2009). A key challenge to the urbanisation process is the rapid conversion of large amount of prime agricultural land to urban land use as well as transformation in the livelihoods of peri-urban dwellers (Owusu \& Agyei, 2007). Urban dwellers purchase almost all their food as well as other goods and services, including housing, transportation, healthcare and education (Cohen \& Garret, 2009). Thus the emergence of urban monetary economy which allows the quantification of every commodity in monetary terms subjects people living in peripheral villages to hardships. From the positive side, urban expansion creates opportunities in wage employment and trading for people in peri-urban areas, and provides them with access to services and infrastructure (Aberra \& King, 2005). To mitigate the negative effects and tap the benefits of urban expansion, a range of livelihood strategies are designed to build asset bases and access to goods and services for consumption. Diverse livelihood portfolios are viewed as a critical component of household economies in developing countries (Cinner \& Bodin, 2010). This is a typical characteristic of peri-urban households since they are influenced by both rural and urban economies.

According to Narrain and Nischal (2007), the peri-urban interface could be understood as a heterogeneous mosaic of natural ecosystems, productive or agro-ecosystems, and urban ecosystems affected by material flows demanded by both urban and rural systems. As a result of the interactions between rural and urban areas, peri-urban dwellers are exposed to a wide range of livelihood options and choices including farm and non-farm based activities that are undertaken in order to achieve their livelihood goals. The occupational sectors include agriculture, salaried work, and informal economic activities such as trading, construction, among others. For this 
reason, a high proportion of households have rural and urban components to their incomes and livelihoods and as a result, individual members engage in different activities in different locations while sharing resources and assets (Satterthwaite et al., 2010). Examining how households access, and depend upon a diversity of occupational sectors is a central theme in many development studies and is often discussed in the context of poverty, urbanisation, household risk, conservation, and coping strategies (Cinner \& Bodin, 2010). The coping strategies discussed in this study are in response to a study conducted earlier in peri-urban Kumasi on the effects of urban expansion on peri-urban livelihoods (Afriyie et al., 2013). The findings of this study indicate that Kumasi's expansion is exposing peri-urban communities to a number of challenges including land use changes, tenure insecurity, pollution, high cost of living and transformation in peri-urban livelihoods. The study reveals that one of the major effects of urbanisation on peri-urban livelihoods is gradual displacement of agricultural activities coupled with high cost of living as a result of the emergence of urban monetary economy. On the other hand, the study also recognises that the expansion of Kumasi is creating non-farm job opportunities, market for vegetable cultivation and increasing access to basic social amenities in the study areas. The main objective of this study is to investigate how peri-urban households strategise to cope with the effects of urbanisation.

\section{Study Methodology}

\subsection{Overview of Study Area}

The study was conducted in the peri-urban Kumasi. The Kumasi Peri-urban Interface (KPUI) has broadly been defined as the zone within a $20 \mathrm{~km}$ to $40 \mathrm{~km}$ radius of the city, although this is a fluid frontier that is constantly changing (Aberra \& King, 2005). The KPUI is undergoing dramatic changes including emergence of multiple land use, influx of new comers and rise in rent as a result of rapid urban growth. Three peri-urban communities (Esereso, Deduako, Appiadu) were selected (Figure 1).

Kumasi is the capital of Ashanti Region and the seat of the Ashanti Kingdom. It is located in the transitional forest zone and is about $270 \mathrm{~km}$ north of the national capital, Accra. It is bounded to the north by Afigya Kwabre District and Kwabre East District, to the east by Ejisu-Juabeng District and Bosomtwe District, to the west by Atwima Nwabiagya District and to the south by Atwima Kwanwoma District.

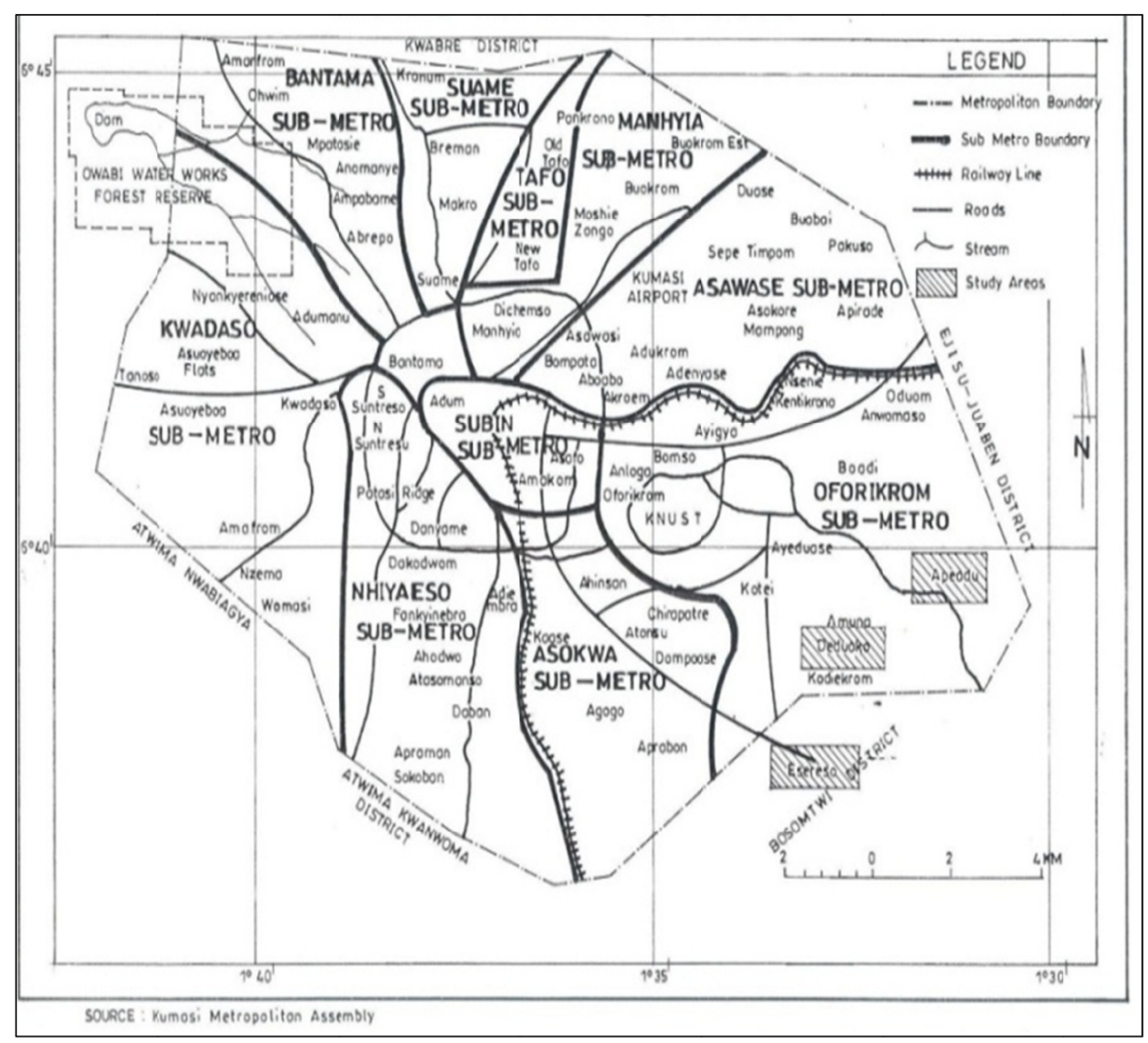

Figure 1. Map of Kumasi Sub-Metropolitan areas showing the study areas 
The population of Kumasi has increased at an unprecedented pace between 2000 and 2010, with an estimated annual population growth rate of 5.4 percent having increased from 5.2 percent per annum between the 1984 and 2000 inter-censal years. These growth figures have all been about twice the national growth rate of 2.7 percent (1984-2000) and 2.4 percent per annum recorded between the year 2000 and 2010 (Afrane \& Amoako, 2011). While the national rate of population increase is reducing that of Kumasi is increasing at an uncontrollably high rate and is currently accommodating a third of the Ashanti region's population (KMA, 2010). The reasons are obvious. Kumasi is both the capital of the Asante State and the Ashanti region. Its strategic central location as a nodal city with major arterial routes linking other parts of the country as well as its rich forest and other natural resource endowments engineered the city's role as a transit point and a powerful commercial hub for migrants from both the northern and southern parts of the country and beyond. Historical antecedents of the city have played no mean a role in consolidating the rich cultural heritage of the city (Amoako \& Korboe, 2011). These formed the basis of Kumasi's growth as a sovereign traditional administrative capital. Urbanisation in Kumasi is thus mainly due to the rapid increase in population as a result of urban development factors including its status as the regional capital, concentration of industrial activities and as the most commercialised centre in the region. Many of the surrounding villages have been swallowed up by the growth of Kumasi.

\subsection{Data Collection and Analysis}

The data for this study was collected through a combination of both qualitative and quantitative methods obtained from primary and secondary data sources. Primary data was collected through Focus Group Discussion (two focus group discussions were held in each community, one from each social class (men and women); questionnaires and interviews with household heads, key informant interviews, and observation. Secondary data sources included content analysis of documents relating to effects of urbanisation on peri-urban livelihoods and their coping strategies.

Three peri-urban communities within $20 \mathrm{~km}$ radius from the city were purposively selected to represent peri-urban Kumasi. The selection was based on the co-existence of rural and urban livelihoods, proximity to Kumasi and the fact that these are places where multiple livelihood types are evolving in response to the effects of urbanisation. The study made use of snowball and purposive sampling techniques to select respondents due to the unavailability of records on people who have lost their farmlands to urban use. The household was the key unit of analysis where only heads of households were interviewed. Household was defined as 'a group of people living and sharing meals cooked from one pot' and taking individual and collective decision within domestic units. This excludes family members living elsewhere (Preston, 1994; Brook \& Dávila, 2000). A total of 150 heads of indigenous households were interviewed, fifty (50) from each community. Respondents were classified according to their major economic activities or sources of livelihoods in order to compare their responses. They were categorised into farm and non-farm employment (occupations other than agriculture). Statistical Product for Service Solution (SPSS) was used to analyse quantitative data and the results are presented in frequency tables, cross-tabulations, bar graphs and bar charts. Qualitative data was tape-recorded and transcribed. Direct quotations from respondents are used to analyse qualitative data.

\section{Conceptual Framework}

The strategies adopted by peri-urban households to cope with the effects of urbanisation are discussed in relation to the DFID's Sustainable Livelihood Framework (SLF) but a modified version (Figure 2) was adopted. The Sustainable Livelihoods Approach centres on both people and their livelihood; prioritising both the tangible and intangible assets they utilise to achieve their desires. It also considers the vulnerable environment the poor operate in and their ability to withstand shocks and stresses, amidst external forces such as policies that affect accessibility of the assets that the people depend upon. A livelihood comprises of capabilities, assets (both material and social resources) and activities required for a means of living (Chambers \& Conway, 1992). A livelihood is considered sustainable when it can cope with and recover from stress and shock, maintain or enhance its capabilities and assets, and provide sustainable livelihood opportunities for the next generation and contributes net benefits to other livelihoods at the local and global levels and in the long and short term. 


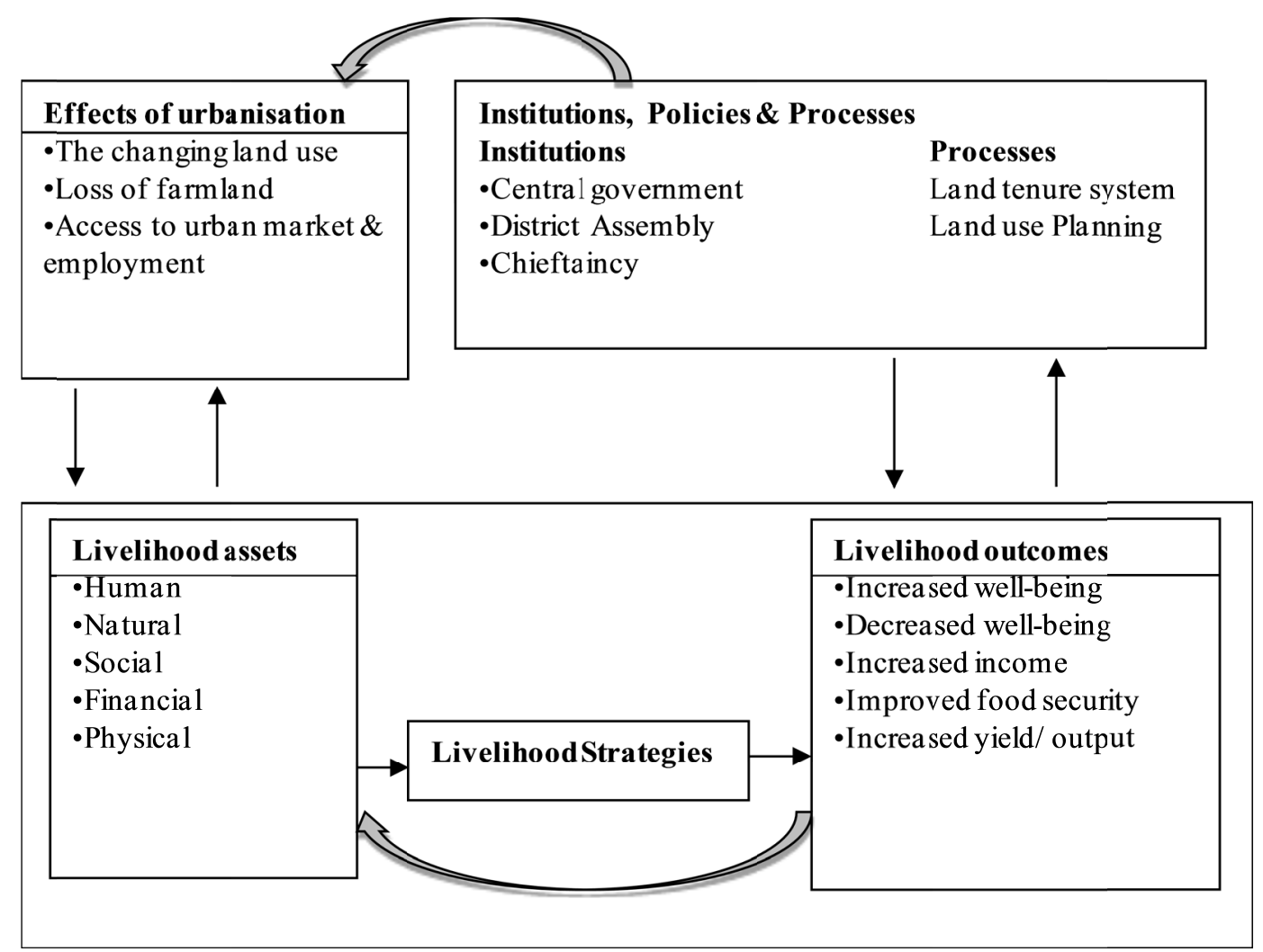

Figure 2. Effects of urbanisation and coping strategies: a conceptual framework

Adapted from DFID (1999).

The SLF is modified because the elements which make up the vulnerability context in the SLF are numerous which make it impossible to develop a full understanding of all dimensions (DFID, 1999). Moreover, the effects of urbanisation do not only make people vulnerable as in the case of vulnerability context but also present countless opportunities to people living in peri-urban areas. The study therefore identifies urban expansion as the context within which peri-urban livelihood is organised and as the external environment within which peri-urban households have limited or no control.

In the process of the horizontal expansion of cities, assets are both destroyed and created. This is evidenced in the constraints and opportunities that urbanisation presents including changing land use, loss of farmland, access to urban market and urban wage employment opportunities. These are external factors that directly constrain or enhance household asset status. Peri-urban households dwell on diverse livelihood resources in order to develop their livelihood strategies and outcomes in response to urbanisation process. The range of assets that people have in their possession contributes to how they are able to manoeuvre their way through the opportunities and constraints of urbanisation. The livelihood assets include natural capital, human capital, financial capital, social capital and physical capital.

The range of assets available to individuals, households and communities translate into livelihood strategies aimed to achieve livelihood outcomes. When farmlands are converted to non-agricultural purposes as observed in the three communities studied, peri-urban dwellers resort to all kinds of livelihood strategies including farming, migration and non-farm income generating activities to cope with this new development. These strategies are the means, choices or the activities that people undertake to achieve livelihood outcomes. The activities adopted may either be natural resource based or non-natural resource based which are undertaken for either a short-term or long-term period. Livelihood strategies in turn reduce vulnerability of the poor by increasing asset base of households through increased income, improved wellbeing, improved food security among others or make them more vulnerable by worsening their livelihood conditions. The outcomes will in turn give a direct feedback to livelihood assets and activities. There is a complementary or cyclical relationship between assets, activities and outcomes. 
The livelihood assets available to individuals, households and communities also influence transforming structures and processes. Greater asset endowment means more influence that individuals can exert. Most often, policy interventions are directed towards areas most endowed with resources. Moreover, people who have accumulated more capital assets are able to actively involve themselves in decision making process regarding issues of access to resources. People with limited access have little influence on transforming structures and processes and this makes them more vulnerable. Increased vulnerability of the poor calls for the intervention of institutions and policies to mitigate the imbalances of urbanisation.

Livelihood strategies and outcomes are not just dependent on access to capital assets or constrained by vulnerability context, they are also transformed by the environment of structures and processes which may facilitate or deny entitlements (Serrat, 2008). Institutions create and determine vulnerability context, assets and outcomes. Institutions and policy interventions serve as the external mediating environment that helps urban systems to cope with, and adapt to the negative consequences of urbanisation. In the peri-urban area, a number of political and social/cultural institutions set and implement policy, deliver services and function in various ways to determine who can access what asset and how such asset must be used. Examples of such institutions operating at different levels of government include central government, local government, Chiefs, non-governmental organisations, social groups and their various policy interventions including land use planning, land tenure system, gender norms among others. Policies are both a result of the national development strategies and factors that induce structural change. It is in the process of sector restructuring induced by policies that the conditions in which households get access to capital are modified (Hinojosa, 2009).

Institutions enable people to achieve positive livelihood outcomes by providing enabling environment for people to pursue their livelihood strategies. This is done through the formulation and implementation of policies and provision of structures such as markets to transform one type of asset into another. Availability of and access to market widens the scope for non-agricultural income generating employment. These interventions aim at making people more resilient by supporting them to build their assets and translating them into livelihood strategies and outcomes. Improvement in transportation system opens a window for people to get access to the city centre to transact business.

Institutions do not only enable people to achieve positive livelihood outcomes, they also act as barriers to a sustainable livelihood. Socio-cultural institutions can have a profound influence on poor households' access to resources (Farrington et al., 2002). Availability of and access to resources consequently affect the strategies adopted by households to cope with the process of urbanisation. For instance, accessibility to natural resources such as land is determined by chiefs and their council of elders at the community level. The sale of farmlands for non-agricultural purposes to urban developers deprives farmers of their livelihoods by reducing the natural capital base.

Looking at the multifaceted nature of the factors that shape peri-urban livelihoods, any interventions aimed at either mitigating the negative effects of urbanisation or developing the opportunities that urbanisation presents must be pro-poor. It must clearly seek to establish the linkages between multiple sectors and develop livelihood assets holistically. Identifying the problems and addressing them in isolation will not serve the purpose of the framework. In this regard Farrington et al. (2002) identify that one area of policy that has the potential for building the security of poor households' livelihood is that of pro-poor policy. People rather than resources or institutions should be the focus of any development strategy. It is within this framework that this paper examines the coping strategies of peri-urban community dwellers of Kumasi in the face of urbanisation.

\section{Results and Discussions}

\subsection{Land Use Change in Kumasi}

Land use changes from agricultural to urban use mostly in the form of residential buildings are the clearest expression of Kumasi's horizontal expansion. The changes in land use pose a serious threat to peri-urban livelihood since according to Davila (2002) most households in the peri-urban area depend on land either for food, water, or fuel wood.

The change detection analysis from the 2007 satellite image shows that Kumasi has greatly expanded to absorb more than half of KMA (Afriyie et al., 2013). A comparison of the 1986 and 2007 satellite images demonstrate an inverse relationship between urban expansion and farmland loss and other natural land cover types (Plate 1). Between 1986 and 2007, the proportion of urban share of the KMA increased from $12.10 \%$ to $63.7 \%$ while the extent of farmland, vegetation and water drastically reduced from $72.30 \%$ to $30.8 \%, 14.7 \%$ to $5.2 \%$ and $0.9 \%$ to $0.38 \%$ respectively (Afriyie et al., 2013). The results confirm a similar study conducted by Attua and Fisher (2011) in the New Juaben Municipality. Their findings reveal that the total urban area increased from $49.24 \%$ in 
2000 to $59.19 \%$ in 2003 , while vegetative cover diminished in extent from $63.7 \%$ to $40.8 \%$ during the same period. This trend, if not proper managed could lead to land management issues and conflicts in Kumasi and its peri-urban interface.

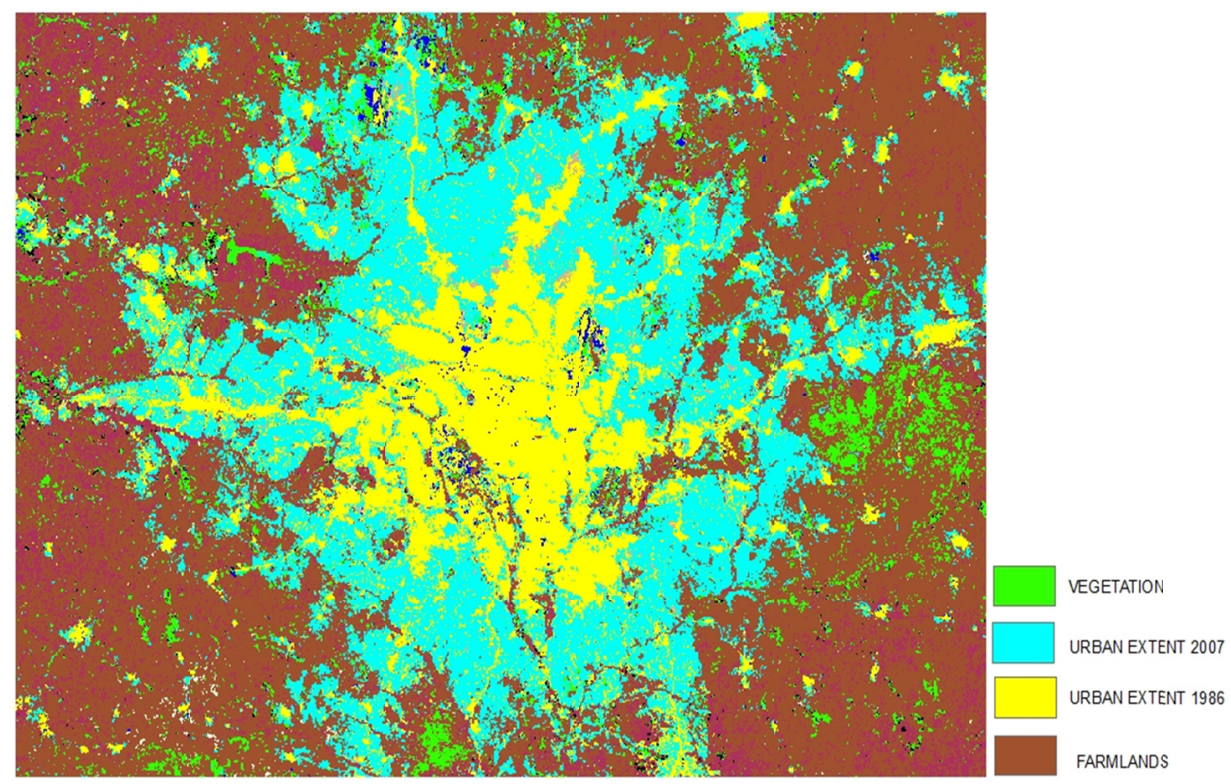

Plate 1. Urban extent for 1986 and 2007

Source: 1986 Landsat TM image and 2007 Landsat EMT+ image analysis, 2011.

\subsection{Urbanisation of Peri-Urban Kumasi: The Effects}

Conversion of agricultural lands to residential buildings is identified as one of the key findings of the research. As high as $98.7 \%$ of the total respondents indicate that the horizontal expansion of Kumasi has taken over agricultural lands (Table 1). This problem is largely attributed to the influx of migrants into the communities which has increased demand for land and its economic value. The increased demand for land in the communities could be due to Thuo's (2010) claim that rent value in the peri-urban areas is relatively cheaper than the land within the city and according to Kasanga and Kotey (2001), in the Kumasi peri-urban area, once a layout/planning scheme has been initiated or approved, farmers either immediately or eventually lose total control of their farmland. Constant conversion of agricultural lands to urban uses has reduced the size and quality of farmlands available for farming.

Table 1. Respondents' views on the relationship between Kumasi's expansion and loss of farmlands

\begin{tabular}{lccc}
\hline & \multicolumn{2}{c}{ Views of Respondents } & Total \\
\cline { 2 - 3 } Age of Respondents & Yes & No & 28 \\
\hline Under 30 years & 26 & 2 & 99 \\
Between 30-60 years & 99 & 0 & 23 \\
Over 60 years & 23 & 0 & 150 \\
Total & 148 & 2 & 100.0 \\
Percentages & 98.7 & 1.3 & \\
\hline
\end{tabular}

Source: Field Survey, 2011.

The reduction in farmland sizes has culminated in a reduction in the number of people engaged in agricultural activities. For instance, data on household heads' previous and current major sources of livelihood (Figure 3) 
indicate that there has been shrinkage in the number of people employed in the agricultural sector. Previously as many as $89.3 \%$ had farming as their major source of livelihood as against only $10.7 \%$ who were non-farmers. Currently, $40 \%$ of the respondents are engaged in farming as their primary economic activity while $60 \%$ are into non-farming income generating activities. The changes in land use and ownership in the study areas have forced people out of land-based (farming) livelihood activities since it is difficult getting easy access to farmlands.

The same story is told in peri-urban Nyahururuu in Kenya by Mandere et al. (2010). The outcome of their study reveals that over $90 \%$ of the respondents were full time farmers in the 1960 s but this has since reduced to $49 \%$ with the remaining households only cultivating their land on part time basis. The current study shows that though agriculture still remains one of the important economic sectors in the study areas, its economic value is significantly declining as a result of the declining number of households that engage in agriculture as full time economic activity. The percentage engaged in farming is most likely to fall due to competing demand for land in the study areas for other activities and as Lei and Bin (2008) projected, "there will be no land for future use if urbanisation is not controlled".

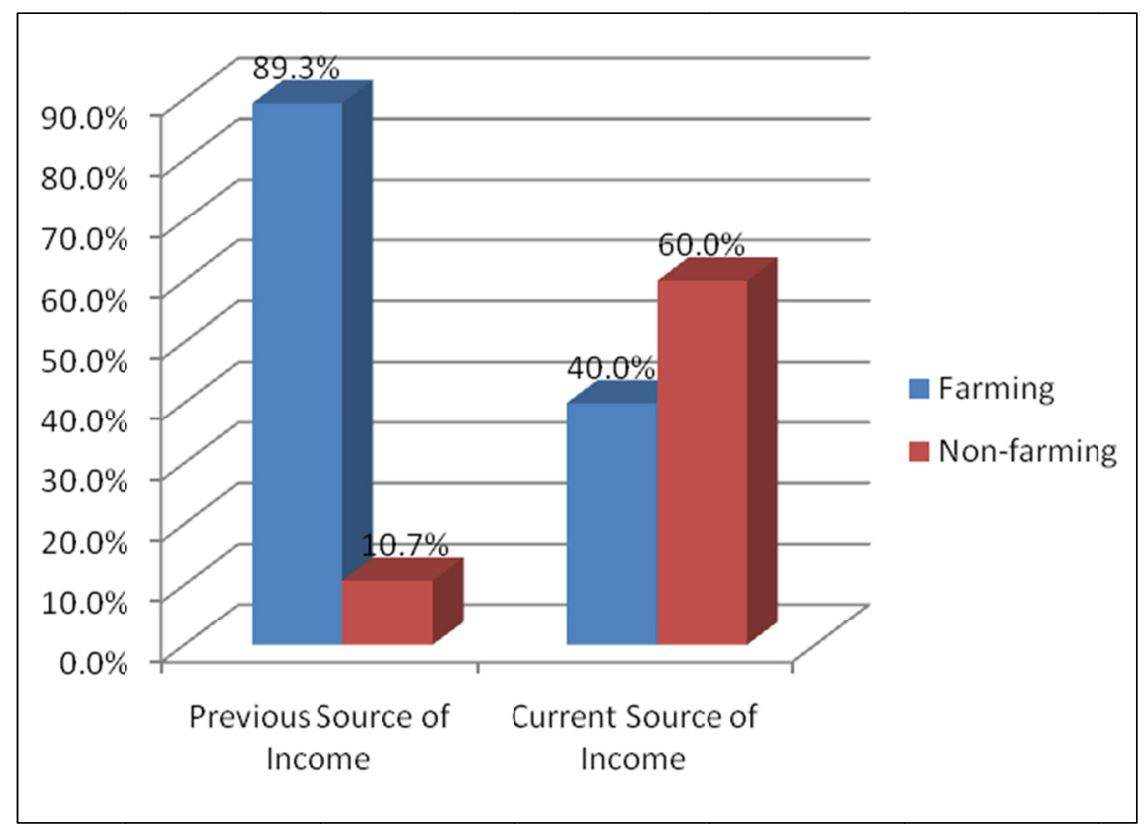

Figure 3. Previous and current main source of income of household heads

The displacement of agricultural activities in the study areas has brought hardships and increased the cost of food since respondents now have to pay for the food they consume. An old lady in Deduako commenting on the effects of Kumasi's expansion and cost of living said that:

It has become difficult to make a living because you can eat only when you have money to buy food. Previously the entire 'new site' was farmland. I grew my own food, I could get vegetables and food stuffs from the farm without paying for it, but now I virtually buy everything even pepper since I no longer have land to farm... We are suffering.

With the emergence of urban economy, most people in the study areas resort to cash income jobs to survive through the emerging urban monetised economy. The growing constraints on agricultural employment and the alternative job opportunities presented by urban expansion have resulted in the growth of non-farm income generation activities in the communities (Figure 3). Though loss of farmlands is identified as one of the constraints presented to the communities, the growth of Kumasi has largely been a blessing to the people living in these communities. Respondents indicate that urbanisation of their communities has given them greater access to different cash income job opportunities. Examination of the kind of job opportunities that have been created in the communities indicates that households generate income by engaging in occupations such as petty trading $(17.3 \%)$, provision of services $(14.0 \%)$, manufacturing $(13.3 \%)$, artisan $(12.7 \%)$ and construction $(28.7 \%)$ in order to sustain their livelihoods (Table 2). These job opportunities serve as safety nets which absorb the 
indigenous residents who lose their livelihoods to urban uses. The predominance of construction is due to the proliferation of new construction projects such as houses and roads in the peri-urban communities.

Sachet water production, the most predominant industrial activity emerging in the peri-urban area dominates in Esereso and Appiadu. It is argued that the process of peri-urbanism is characterised by changing local economic and employment structures, from agriculture to manufacturing (Hudala et al., 2008). However, observation from the study areas indicates that the process of peri-urbanism in the study areas is not characterised by the concentration of heavy industrial activities as compared to other peri-urban areas in the world (Bah et al., 2003; Mandere et al., 2010; Narrain \& Nischah, 2007). The trend of Kumasi peri-urbanism is characterised by the changing employment structure from purely agricultural activities to mainly commercial activities and low-skill labour rather than heavy concentration of manufacturing industries. This trend of change supports the view presented by Keiser et al. (2004) and Songsore (2009) that urbanisation in Africa is characterised by absence of industrial expansion because many cities in Africa were developed as colonial administrative or trading centres rather than industrial zones.

Table 2. The kind of opportunities presented by the growth of Kumasi

\begin{tabular}{llllll}
\hline Job Opportunities & Esereso & Deduako & Appiadu & Total & Percent \\
\hline Trading & 10 & 14 & 2 & 26 & 17.3 \\
Artisan & 4 & 9 & 6 & 19 & 12.7 \\
Provision of services & 5 & 4 & 12 & 21 & 14 \\
Vegetable farming & 2 & 5 & 1 & 8 & 5.3 \\
Construction & 5 & 10 & 18 & 43 & 28.7 \\
Trading and Artisan & 3 & 8 & 0 & 11 & 7.3 \\
Manufacturing & 9 & 0 & 11 & 20 & 13.3 \\
Total & 48 & 50 & 50 & 50 & 100.0 \\
\hline
\end{tabular}

Source: Field Survey, 2011.

\subsection{Coping Strategies}

\subsubsection{Household Responses to the Dwindling Agricultural Lands}

With the continuous expanding urban areas, livelihood transformation is inevitable. This is due to the transformation in the peri-urban economy from predominantly rural agrarian economy to predominantly urban economy. Transformation in the livelihoods of people who formerly depended on natural resources to survive implies that peri-urban indigenes now have to develop a range of survival strategies to cope with the changes. The options open to households in the communities vary according to sources of livelihood and access to livelihood resources. These strategies are not different from those adopted in other areas and these are discussed according to the classification by Scoones (1998) on the basis of sources of livelihood/major income. Households in the study communities adopt farm strategies, non-farm strategies or a combination of the two to cope with the expansion of Kumasi. These strategies include diversification, intensification and migration with the aim of strengthening household resilience by enhancing income or reducing expenditure.

Table 3 indicates that the increasing pressures from urban expansion have compelled most people to diverse their income sources or secure alternative livelihood other than agriculture as coping strategies. For instance $8.0 \%$ of the respondents diversify their non-farm income (multiple non farm income activities in order to broaden their income base) while $10.7 \%$ engage in a single non-farm alternative livelihood activity. With the expansion of Kumasi, respondents are left with no other alternative than to switch from land-based livelihood activities to non-land based income generating activities. Essentially the most common non-farm activities available in the communities include petty trading/business, artisanry, construction and service provision. Trading in both agricultural produce and manufactured goods remain a significant livelihood activity in the communities most especially for women. Most people in the study areas resort to cash income jobs to survive through the emerging urban monetised economy. In Appiadu, trade in firewood has become important component of household income especially among women. 
Availability of alternative sources of livelihood to absorb displaced farmers is very essential when it comes to risk reduction. The constant conversion of agricultural lands to urban uses forces people to change occupations since it is difficult getting easy access to farmlands. Barret et al. (2001) describe these set of motives as "push" factors that prompt households and individuals to diversify assets. According to Atamanov and Berg's (2011) research findings in Kyrgyz Republic in Central Asia, small land size and poor land quality are in part among the reasons that made individuals choose employment in the non-farm sector over agricultural activities. Tacoli (2004) describes this as a survival strategy for vulnerable households and individuals who are pushed out of their traditional occupations and who must resort to different activities to minimise risks and make ends meet. Survival strategy is often seen as last resort activities for poor households. For instance, according to Thuo (2010), most families in Nairobi peri-urban areas formerly relying on farm for food and income turn to look for non-farm jobs within their locality or elsewhere with the declining agricultural opportunities due to land conversions and population increase.

Table 3. Respondents' coping strategies to urbanisation

\begin{tabular}{|c|c|c|c|c|}
\hline \multirow[t]{2}{*}{ Strategies } & \multicolumn{2}{|c|}{ Major source of income } & \multirow[b]{2}{*}{ Total } & \multirow[b]{2}{*}{ Percent } \\
\hline & Farming & Non-farming & & \\
\hline Diversify crop production & 5 & 0 & 5 & 3.3 \\
\hline Diversify non-farm income & 0 & 12 & 12 & 8.0 \\
\hline Diversify farm and non-farm income & 11 & 3 & 14 & 9.3 \\
\hline Intensify crop production & 13 & 0 & 13 & 8.7 \\
\hline $\begin{array}{l}\text { Secure alternative livelihood other } \\
\text { than agriculture }\end{array}$ & 0 & 16 & 16 & 10.7 \\
\hline Migrate to look for employment & 9 & 3 & 12 & 8.0 \\
\hline $\begin{array}{l}\text { Diversify crop production, diversify } \\
\text { farm \& non-farm income, intensify } \\
\text { crop production and secure } \\
\text { alternative livelihood }\end{array}$ & 5 & 0 & 5 & 3.3 \\
\hline $\begin{array}{l}\text { Intensify crop production \& secure } \\
\text { alternative livelihood }\end{array}$ & 6 & 3 & 9 & 6.0 \\
\hline $\begin{array}{l}\text { Diversify farm \& non-farm income } \\
\text { and secure }\end{array}$ & 11 & 53 & 64 & 42.7 \\
\hline \multicolumn{5}{|l|}{ alternative livelihood } \\
\hline Total & 60 & 90 & 150 & 100.0 \\
\hline
\end{tabular}

Source: Field Survey, 2011.

Secondly, the exposure of the communities to urban monetary economy serves as a 'pull factor' attracting the affected farmers to take advantage of the alternative non-farm employment opportunities that urbanisation presents. The increasing polarisation of non-farm employment could be due to Aberra and King's (2005) view that urbanisation creates opportunities in wage employment and trading, and provides access to services and infrastructure leading to the evolution of different livelihood types. According to the respondents, non-farm employment pays well and involves lower risks as compared to agriculture. Tacoli (2004) describes these set of motives as accumulation strategy for wealthier groups with better education and skills. According to her, these people can be pulled by new opportunities, and their accumulation strategies aim to draw maximum benefits from the changing context.

In response to the declining agricultural land in the communities, farmers shifted to cultivating early-maturing and high-yielding crops. They resorted to intensification and diversification of crops. The survey results indicate that respondents resort to diversify (3.3\%) and intensify crop production (8.7\%) to cope with urbanisation. Crop diversification in the study areas includes growing multiple food crops on a field. This is mostly on subsistence level where crops such as plantain, cassava, maize, pepper, okro are cultivated on the same piece of land. This strategy is adopted to secure livelihood or reduce risk associated with mono-cropping. Another farm strategy 
adopted in the communities is intensive production. Crop intensification is adopted to either enhance household food security as a supplement or as a major source of income. This has become a very important source of sustenance to most households due to its potential to reduce household expenditure on food since according to Satterthwaite et al. (2010) and Matuscke (2009), majority of urban dwellers are net food buyers and spend a large part of their disposable income on food.

Intensive cultivation of vegetables is stimulated by the increasing demand for vegetables in the city. Agricultural production is increasingly commercialised in the communities. The rising demand for high-value crops such as cabbage, shallot among others from urban markets has resulted in people diverting to the cultivation of these vegetables. Intensification is characterised by the use of fertilizer, irrigation, pest and weed control management to increase crop yield and income from agricultural production. However, application of fertilizer and irrigation is mostly common with commercial vegetable growers. Farmers who cultivate on subsistence level still rely on the rain. Another peculiar characteristic of farming in the communities is that farming is mostly done on any land that is yet to be developed including farming along river banks, on building sites, open spaces and backyard farming. With the exception of exotic vegetable farming that is mostly done along river banks or water catchment areas, crop farming is mostly on subsistence basis. Tenure insecurity which often leads to premature loss of crops is identified as one of the major problems facing farmers in the communities. Nobody opted for extensification as a livelihood strategy as land commercialisation in the communities has rendered large scale cultivation of cash crops economically unviable. This could be due to the explanation given in the work of Thuo (2010) that in the peri-urban Nairobi, since most of the lands have been sub-divided either due to in situ increasing population or immigration leading to land demand for residential purposes, most families have been left with small portions of land for cultivation. Therefore high demand for peri-urban lands and land commodification make it difficult to cultivate on a large scale and the cultivation of cash crops is economically unviable.

The study also reveals that when people cannot gain a secure livelihood in their homeland, they are compelled to migrate. Migration is one of the important strategies whenever people can no longer secure a livelihood. From the survey results, $8.0 \%$ of the respondents indicated that they migrate elsewhere to look for employment. Most of the respondents in this category explain that they migrate seasonally to cocoa growing areas of interior Ashanti, Brong-Ahafo and Western Regions or travel daily to distant rural locations (where large tract of land is available) for extensive cultivation of crops with longer gestation period. Others also migrate to other parts of the country or commute to the city daily to work. Migration is mostly resorted to as the last or the only available option for people when they have limited access to land. A carpenter from Esereso who migrates seasonally to farm comments that:

I used to farm here and at the same time doing my carpentry work. But all the land had been sold, so I have now migrated to Sefwi-Wiawso to farm but occasionally I come back to continue my carpentry work.

A woman from Deduako commenting on migration explains that:

There are no jobs in this community. Most youth in this community are either 'mates' (bus conductors) or drivers. This is the common job available here so those who cannot cope with the situation have all migrated to the city to look for jobs.

The survey also discovers that keeping more than one livelihood activity is one of the strategies most households adopt to strengthen their resilience against shock. The research indicates that most households rarely depend on one strategy to survive. Respondents combine different livelihood strategies in order to cope with Kumasi's expansion. It can also be inferred that a sizeable number of respondents combine both farm and non-farm livelihood activities as their coping strategies. For instance, $42.7 \%$ of the respondents diversify both farm and non-farm income and secure alternative livelihood other than agriculture, 9.3\% diversify farm and non-farm income while $6.0 \%$ of the respondents intensify crop production and secure alternative livelihood other than agriculture (Table 3). The data also shows that non-farming households are more diversified than farming households (Table 3). Greater diversification could be associated with the proliferation of new income generating opportunities in the study areas due to their proximity to Kumasi. This however contradicts a study by Brook and Dávila (2000) in Kumasi peri-urban interface that only $2 \%$ of the respondents engaged in other economic activities to supplement their income.

It can be inferred from the data that changes in the livelihood strategies involve two levels: a change within the same livelihood activity (for instance a farmer switching from cultivation of cassava to the cultivation of vegetables because vegetables have shorter lifespan) and a change from one occupation to other (switching from farming to trading). It is also obvious that certain strategies are peculiar to a particular source of livelihood. For 
instance diversification and intensification of crop production are only associated with households who have farming as their livelihood source while securing alternative livelihood other than agriculture are adopted by those in non-farming income generating activities.

\subsubsection{Responses to Economic Hardships/High Cost of Living}

The loss of farmland is not the only constraint Kumasi's expansion presents to the people living in the peripheral villages. The transition from rural agrarian economy to urban monetary economy allows every commodity or service to be quantified in monetary terms and this serves as constraints on the livelihood of residents as people now have to purchase almost everything they need including food, fuel for cooking, housing, transportation, healthcare, education and other goods and services (Cohen \& Garret, 2009). The study therefore sought to find out how households in the communities respond to such demands on their living conditions. From Table 4, it can be seen that when household food security is threatened by loss of farmland or natural resources needed for food production, respondents resort to reduction in household expenditure on food as a key coping strategy (44 respondents, representing 29.3\%). To cut down cost on food, people devise strategies such as a reduction in the quantity of food purchased (eating less or skipping meals) and quality of food consumed (shifting from the consumption of high value foods). The focus group discussions reveal that people mostly resort to the consumption of street food instead of home-prepared food when food prices and fuel for cooking increases. Most often parents especially mothers sacrifice their meals for their children. An artisan from Esereso makes a comment that:

If GH1 cedi can conveniently guarantee me a ball of kenkey and fried fish, why not spare myself the hassle of going to market to buy corn dough and other ingredients and the cost of preparing it since it is cheaper to buy than to cook it myself.

The transformation in the economies of the study communities has compelled $19.3 \%$ of the respondents to engage in multiple sources of income generating activities whilst $14 \%$ engage children in hawking to off set hardships. A gender dimension of the strategies adopted shows that male-headed households and female-headed households approach hardships differently. Table 4 shows that men are more likely to resort to the reduction in household expenditure while women are more likely to engage children in trading. The reason is not far-fetched. Male-headed households have the final say in the management of household food consumption and financial requirements while according to Brook and Dávila (2000) in the Kumasi peri-urban interface, women are more likely to take to trading which explains why women engage children in trading more than men. Respondents also resort to borrowing $(10 \%)$, sale of assets $(8 \%)$ and reduction in the household expenditure on other services $(12 \%)$.

Table 4. Household responses to high cost of living

\begin{tabular}{lccc}
\hline \multirow{2}{*}{ Household Responses to Hardships } & \multicolumn{2}{c}{ Gender } & \\
\cline { 2 - 3 } & $\begin{array}{c}\text { Male-Headed } \\
\text { Households }\end{array}$ & $\begin{array}{c}\text { Female-Headed } \\
\text { Households }\end{array}$ & Total \\
\hline Engaging in multiple sources of income & 19 & 10 & 29 \\
$\begin{array}{l}\text { Reduction in Household Expenditure on other } \\
\text { Services }\end{array}$ & 11 & 7 & 18 \\
Sale of asset & 3 & 9 & 12 \\
Move to Low Quality Buildings with Low Rent & 4 & 7 & 11 \\
Reduction in Household Expenditure on Food & 31 & 13 & 44 \\
Engaging Children in Hawking & 6 & 15 & 21 \\
Borrowing & 10 & 5 & 15 \\
Total & 84 & 66 & 150 \\
Percentage & 56 & 44 & 100.0 \\
\hline
\end{tabular}

Source: Field Survey, 2011. 
It has been argued that the support base of the household is crucial for the total survival of the members to the extent that the question of how old the person is does not matter as much as how much each individual is able to contribute to the household basket (Ashong et al., 2004). Keeping more household members in different occupations could be seen as a survival strategy adopted by most households to cushion the shock of urbanisation. The study reveals that respondents have diversified range of activities undertaken by different members of the family (diversified intra-household activities). Individual members of the household engage in occupation ranging from farming, trading, construction and services to manufacturing with the sole aim of getting money or food to supplement family income. Gregory (2005) broadly categorised these livelihood activities into cash based and non-cash based activities. The survey (Figure 4), reveals that majority of households (67.3\%) have members (other than the main breadwinner) engaged in cash-income jobs while $20.7 \%$ household heads indicate that their household members are engaged in occupation for food.

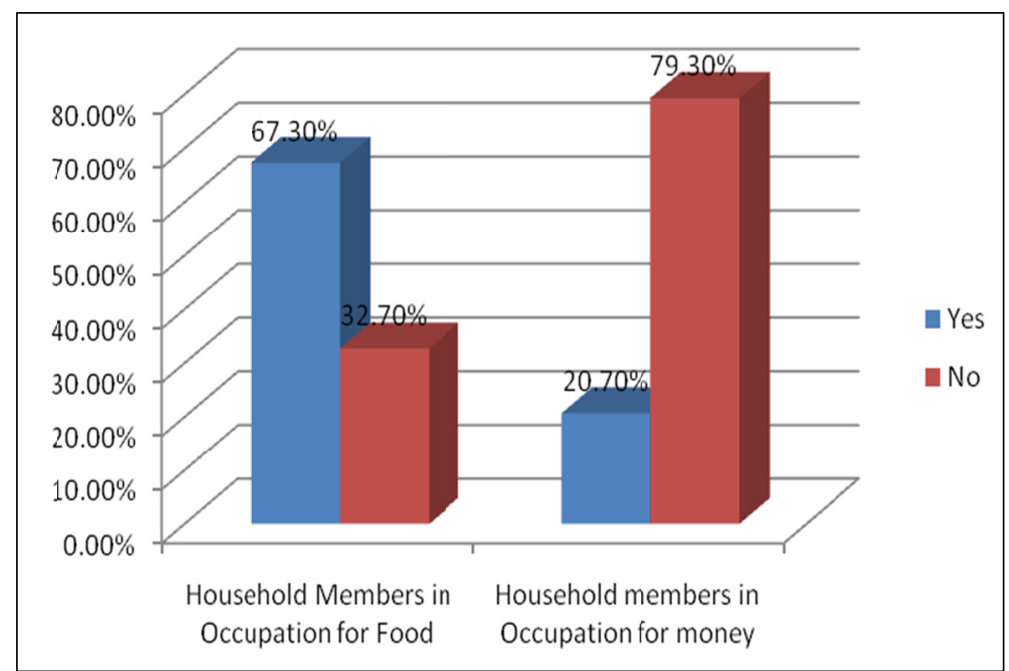

Figure 4. Occupational activities of other members of the household of respondents

Source: Field Survey, 2011.

Even though social and kinship networks are declining, remittances from household members living elsewhere constitute a very important component of the livelihood of respondents. Table 5 reveals that majority of the sampled household heads (78.0\%) receive support from relatives both abroad and in the country. Respondents dwell on the social network base available for support whenever they are in need. However, the support received by respondents is from the immediate nuclear family members. The extended family and kinship networks which formed a very important part of the social capital base in the study areas are increasingly being eroded with the emergence of urbanisation and modernisation. A discussant from Appiadu reveals that they sometimes receive financial support from their church. The findings of Thuo (2010) in Nairobi peri-urban area in Kenya indicate that churches have become new space of communal get-together where members meet to support each other in times of need such as during bereavements, weddings or sickness. Moreover, people also fall on the new emerging social groups such as associations (fun clubs), political groups among others for support in times of need.

The outcome of the strategies signifies how households are able to put both their productive assets (e.g. human capital, land etc) and non-productive assets (household valuables) into proper use in order to effectively develop their livelihood strategies (Barrett et al., 2001). Table 6 shows the outcome of the various livelihood strategies adopted by respondents and effectiveness of the strategies. Out of the total number of household heads interviewed, $21.3 \%$ explain that their income has increased, $40.0 \%$ experienced increased well-being, $8.7 \%$ of the respondents' productivity has increased, $18.0 \%$ achieved food security, $8.7 \%$ are managing (no effect) while only $3.3 \%$ had their well-being decreased. According to the sustainable livelihood framework developed by the DFID (1999), the outcomes of livelihood strategies determine how sustainable or unsustainable a particular livelihood activity is. 
Table 5. Access to financial assistance from relatives

\begin{tabular}{ccc}
\hline Response & Frequency & Percent \\
\hline Yes & 117 & 78.0 \\
No & 33 & 22.0 \\
Total & 150 & 100 \\
\hline
\end{tabular}

Source: Field Survey, 2011.

Table 6. Outcomes of strategies adopted by respondents

\begin{tabular}{|c|c|c|c|c|c|c|c|}
\hline \multirow[t]{2}{*}{ Strategies } & \multicolumn{6}{|c|}{ Outcomes } & \multirow[t]{2}{*}{ Total } \\
\hline & $\begin{array}{l}\text { Increased } \\
\text { income }\end{array}$ & $\begin{array}{c}\text { Increased } \\
\text { well-being }\end{array}$ & $\begin{array}{l}\text { Increased } \\
\text { productivity }\end{array}$ & $\begin{array}{c}\text { Food } \\
\text { security }\end{array}$ & $\begin{array}{l}\text { Decreased } \\
\text { well-being }\end{array}$ & managing & \\
\hline 1 & 1 & 0 & 0 & 3 & 1 & 0 & 5 \\
\hline 2 & 2 & 8 & 0 & 1 & 0 & 1 & 12 \\
\hline 3 & 2 & 7 & 2 & 2 & 0 & 1 & 14 \\
\hline 4 & 1 & 5 & 4 & 2 & 1 & 0 & 13 \\
\hline 5 & 9 & 6 & 0 & 0 & 0 & 1 & 16 \\
\hline 6 & 2 & 2 & 3 & 3 & 1 & 1 & 12 \\
\hline 7 & 1 & 3 & 1 & 0 & 0 & 0 & 5 \\
\hline 8 & 1 & 4 & 1 & 2 & 0 & 1 & 9 \\
\hline 9 & 13 & 25 & 2 & 14 & 2 & 8 & 64 \\
\hline Total & 32 & 60 & 13 & 27 & 5 & 13 & 150 \\
\hline Percent & 21.3 & 40.0 & 8.7 & 18.0 & 3.3 & 8.7 & 100 \\
\hline
\end{tabular}

Source: Field Survey, 2011.

Strategies in Table 6 defined:

$1=$ Diversifying crop production

$2=$ Diversifying non-farm income

$3=$ Diversifying farm and non-farm income

$4=$ Intensifying crop production

$5=$ Securing alternative livelihood other than agriculture

$6=$ Migrate to look for employment

$7=$ Diversify crop production diversify farm\& non-farm income, intensify crop production \&secure alternative livelihoods

$8=$ Intensify crop production \& secure alternative livelihood

9= Diversify farm \&non-farm income and secure alternative livelihood other than agriculture

Those who intensified crop production increased their income, well-being, productivity and achieved food security. Only one person achieved a decreased well-being. Out of the $10.7 \%$ of the respondents who secured alternative strategies other than agriculture, $6 \%$ and $4 \%$ increased income and increased well-being respectively. The households that experienced decreased well-being adopted strategies that relate to farming and migration. The results could mean that since farmlands are constantly being converted to urban uses, there might not be large tract of land that will allow for extensive cultivation. The implication is that the traditional method of farming in peri-urban areas is no longer a viable means of livelihood. 


\section{Conclusion and Recommendations}

The study reveals that the combined negative and positive effects of urban expansion have culminated in the adoption of both farm and non-farm livelihood strategies including intensification and diversification of resources and migration to either develop the potentials that urbanisation presents or reduce the extreme effects of urbanisation. These strategies are largely determined by the nature of the effects of urbanisation on respondents' livelihoods. Based on the results from the study, it is established that non-farming households have more diversified livelihood strategies than farming households.

The study broadly classifies these livelihood strategies into farm and non-farm income generating activities. Household members either change occupations (for example changing from farming to trading/vertical movement) or switch from one livelihood activity to another similar livelihood activity (for example changing from the cultivation of maize to cabbage/ horizontal movement) or diversify their livelihood sources. They resort to intensification, migration and diversification of resources in order to cope with urban expansion. It is discovered that most households in the study areas rarely depend on one livelihood activity to survive. Households combine both farm and non-farm strategies in order to cope with the effects of urbanisation. The study also discovers that most households keep household members in different occupations as a survival strategy to cushion the shock of urbanisation. Activities that make direct contributions towards household consumption are preferred (e.g. crop farming and trading of food items). One useful observation from this study is that livelihood activities that generate income regularly are more appropriate within a monetised peri-urban economy. This obviously is the surest guarantee for survival.

The results from the survey also revealed that with the dwindling land size and commercialisation of peri-urban lands, people who still engage in farming employ all forms of strategies to increase productivity. Farmers in most cases farm on any available yet to be developed parcel of land (open space), along riverbanks, drains and catchment areas of rivers/streams. Moreover, agricultural practices have changed from extensive cultivation of cash crops to intensive cultivation of vegetables. Farmers support the intensive farming system with application of fertilizer, irrigation, pest control management and soil maintenance to protect the integrity of the soil and to increase productivity.

The research provides evidence to the effect that peri-urban livelihoods exhibit distinctive features, which must be taken into consideration in pro-poor policy design and implementation. Vegetable cultivation has a high potential for generating income for poor households in the peri-urban Kumasi. To succeed however, farmers will require financial support to overcome problems of high cost of seeds and pesticides.

Based on the findings of the study, the study recommends a speed up work on the urban policy leading to its full implementation. The land policy should also be fully implemented. The Land Administration Project must also be fast-tracked to bring harmony in the land market. The research recommends that through a planned programme and coordinated efforts, alternative means of livelihood be provided in these communities to ensure a proper integration of peri-urban dwellers into urban monetary economy. This can be done through the diversification of the peri-urban economy and development of the non-farm income generating activities. Peri-urban agriculture should also be encouraged in the form of intensive agriculture to ensure sustained urban and peri-urban food supply. Avenues for skills training and development could be created. It is important to encourage women's acquisition of skills as this contributes to the sustainability of peri-urban livelihoods. Access to credit should be expanded to cover the peri-urban poor. The District Assemblies, traditional rulers in partnership with other agencies have essential and critical roles to play. District Assemblies and the local authorities in discharging these responsibilities must overcome among other constraints inadequate human and financial resources, land disputes and undue political interference.

\section{References}

Aberra, E., \& King, R. (2005). Additional Knowledge of Livelihoods in the Kumasi Peri-Urban Interface (KPUI), Ashanti Region, Ghana, Development Planning Unit, and University College London. Retrieved October 2, 2010, from http://www.nrsp.org.uk/database/documents/2813.pdf

Afrane, S., \& Amoako, C. (2011). Peri-Urban Development in Kumasi. In K. K. Adarkwa (Ed.), Future of the Tree: Towards Growth and Development of Kumasi University Printing Press, KNUST, Kumasi.

Afriyie, K., Abass, K., \& Adomako, J. A. A. (2013). Urbanisation of the Rural Landscape: Assessing the Effects in Peri-urban Kumasi. International Journal of Urban Sustainable Development. Forthcoming. 
Amoako, C., \& Korboe, D. (2011). Historical Development, Population Growth and Present Structure of Kumasi. In K. K. Adarkwa (Ed.), Future of the Tree: Towards growth and development of Kumasi University Printing Press, KNUST, Kumasi.

Ashong, K., Adjei, B. F., Ansah, E. O., Naaso, R., King, R. S., Kunfa, E., Quashie Sam, J. S., ... Simon, D. (2004). Who can help the Peri-Urban Poor? (Boafo ye na) Adoption and Impact of Livelihood Activities on Community Members in the Kumasi Peri-Urban Interface-R8090 Revised Research Report 4, CEDEP-Kumasi, Ghana, KNUST-Kumasi, Ghana, CEDAR-Surrey, UK.

Atamanov, A., \& Berg, M. (2011). Microeconomic Analysis of Rural Non-farm Activities in the Kyrgyz Republic: What Determines Participation and Returns? (pp. 8-13) Maastricht Graduate School of Governance, University of Maastricht, Maastricht and Development Economics, Wageningen University, Wageningen, The Netherlands.

Bah, M., Cissé, S., Diyamett, B., Daillo, G., Lerise, F., Okali, D., ... Tacoli, C. (2003). Changing Rural-Urban Linkages in Mali, Nigeria and Tanzania. Environment and Urban, 15(1), 18.

Barrett, C. B., Reardon, T., \& Webb, P. (2001). Nonfarm Income Diversification and Household Livelihood Strategies in Rural Africa: Concepts, Dynamics, and Policy Implications. Food Policy, 315-331. http://dx.doi.org/10.1016/S0306-9192(01)00014-8

Brook, R. M., \& Dávila, J. D. (2000). The Peri-Urban Interface: A Tale of Two Cities. School of Agricultural and Forest Sciences, University of Wales and Development Planning Unit, University College London.

Chambers, R., \& Gordon, C. (1992). Sustainable Rural Livelihoods: Practical concepts for the $21^{\text {st }}$ Century. IDS Discussion Paper 296, IDS, Brighton, UK.

Cinner, J. E., \& Bodin O. (2010). Livelihood Diversification in Tropical Coastal Communities: A Network Based Approach to Analysing 'Livelihood Landscapes'. PLos One, 5(8), e11999. http://dx.doi.org/10.1371/journal.pone.0011999

Cohen, J. M., \& Garret, L. J. (2009). The Food Price Crises and Urban Food (in) security. Sage Publications on behalf of IIED: 469-470. Retrieved January 9, 2011, from http://eau.sagepub.com/content/22/2/467

Department for International Development (DFID). (1999). Sustainable Livelihoods Guidance Sheets.

Ferrington, J., Rasmut, T., \& Walker, J. (2002). Sustainable Livelihood Approaches in urban areas: General Lessons, with illustrations from Indian cases. ODI, London.

Gregory, P. (2005). A Synthesis of Peri-urban Research of Kumasi, Hubli-Dharwad and Kolkata Peri-urban Interfaces. Final Report on Project R8491, DFID Natural Resources Systems Programme, Development Planning Unite, University College London. Retrieved July 23, 2010, from http://www.ucl.ac.uk/dpu/pui/research/previous/synthesis/index.html

Hinosa, L. (2009). EU-Mercousur Trade Agreement: Potential Impacts on Rural Livelihoods and gender (with focus on biofuels feedstock expansion). Brooks World Poverty Institute and Impact Assessment Research Centres, School of Environment and Development, University of Manchester, UK. Retrieved November 10, 2009, from www.mdpi.com/journal/sustainability

Hudala, D., Winarso, H., \& Woltjer, J. (2008). Peri-urbanisation in East Asia: A New Challenge for Planning. International Development Planning Review, 29(4). http://dx.doi.org/10.3828/idpr.29.4.4

Keiser, J., Utzinger, J., Caldas de Castro, M., Smith, A. T., Tanner, M., \& Singer, H. B. (2004). Urbanisation in Sub-Saharan Africa and Implication for Malaria Control. Office of population Research, Princeton University, Princeton, New Jersey.

Kumasi Metropolitan Assembly (KMA). (2010). KMA Medium Term Development Plan 2010-2013. Kumasi: Ministry of Local Government, Rural Development and Environment, Ghana.

Lei, Q. I., \& Bin, L. U. (2008). Urban Sprawl: A Case Study of Shenzhen, China. $44^{\text {th }}$ ISOCARP Congress.

Mandere, M. N., Ness, B., \& Erberg, S. (2010). Peri-urban Development, Livelihood Change and Household Income: A Case Study of Peri-urban Nyahururu, Kenya. Journal of Agricultural Extension and Rural Development, 2(5), 73-79. Retrieved August 17, 2010, from www.academicjournal.org/JAERD

Matuscke, I. (2009). Using Food Density Maps to Identity Future Food Security Hotspots. Global Perspective Studies Unit, Food and Agriculture Organisation of the United Natons, Contributed Paper Prepared for Presentation at International Association of Agricultural Economists Conference, Beijing, China: p. 2. 
Narain, V., \& Nischal, S. (2007). The Peri-urban Interface in Shahpur Khurd and Karnera, India. Environment and Development, 19(1), 261-273. http://dx.doi.org/10.1177/0956247807076905

Olujimi, J. (2009). Evolving a Planning Strategy for Managing Urban Sprawl in Nigeria. Journal on Human Ecology, V25(3), 201-208. Kamla-Raj.

Owusu, G., \& Agyei, J. (2007). Changes in Land Access, Rights an Livelihoods in Peri-urban Ghana: The case of Accra, Kumasi and Tamale metropolis. Accra: ISSER.

Satterthwaite, D., McGranahan, G., \& Tacoli, C. (2010). Urbanisation and its Implication for Food and Farming, Royal Society Publishing. Phil. Trans. R. Soc. B, 365, 2809-2820. Retrieved August 1, 2011, from rstb.royalsocietypublishing.org

Scoones, Ian. (1998). Sustainable Rural Livelihoods: A Framework for Analysis. IDS Working Paper No. 72; Brighton, Institute of Development Studies.

Serrato, O. (2008). The Sustainable Livelihood Approach, Asian Development Bank, Manila, Philippines. Retrieved November 7, 2009, from http:// www.livelihoods.org/index.html

Songsore, J. (2009). The Urban Transition in Ghana: Urbanisation, National Development and Poverty Reduction. A Study Prepared for the IIED as Part of its Eight Country Case Studies on Urbanisation.

Tacoli, C. (2004). Rural-urban linkages and pro-poor agricultural growth: an overview. IIED, UK.

Thuo, A. D. M. (2010). Community and Social Responses to Land Use Transformations in the Nairobi Rural-urban Fringe, Kenya, Field Actions Science Reports, Special Issue 1-Urban Agriculture. Retrieved August 1, 2009, from http://factsreports.revues.org/index435.html

Xie, Y., Fang, C., Lin, G. C. S., Gong, H., \& Qiao, B. (2007). Tempo-Spatial Patterns of Land Use Changes and Urban Development in Globalising China: A Study of Beijing. Sensors, 2881-2882. http://dx.doi.org/10.3390/S7112881

\section{Copyrights}

Copyright for this article is retained by the author(s), with first publication rights granted to the journal.

This is an open-access article distributed under the terms and conditions of the Creative Commons Attribution license (http://creativecommons.org/licenses/by/3.0/). 